\title{
Influence of Iron Addition (Alone or with Calcium) to Elements Biofortification and Antioxidants in Pholiota nameko
}

\author{
Sylwia Budzyńska ${ }^{1, *(D)}$, Marek Siwulski ${ }^{2}$, Zuzanna Magdziak ${ }^{1}\left(\mathbb{D}\right.$, Anna Budka ${ }^{3}$, Monika Gąsecka ${ }^{1}$ (D), \\ Pavel Kalač ${ }^{4}$, Piotr Rzymski ${ }^{5,6}{ }^{(D}$, Przemysław Niedzielski ${ }^{7}$ (D) and Mirosław Mleczek ${ }^{1}$
}

1 Department of Chemistry, Faculty of Forestry and Wood Technology, Poznań University of Life Sciences, Wojska Polskiego 75, 60-625 Poznań, Poland; zuzanna.magdziak@up.poznan.pl (Z.M.); monika.gasecka@up.poznan.pl (M.G.); miroslaw.mleczek@up.poznan.pl (M.M.)

2 Department of Vegetable Crops, Faculty of Agriculture, Horticulture and Bioengineering, Poznań University of Life Sciences, Dabrowskiego 159, 60-594 Poznań, Poland; marek.siwulski@up.poznan.pl

3 Department of Mathematical and Statistical Methods, Poznań University of Life Sciences, Wojska Polskiego 28, 60-637 Poznań, Poland; anna.budka@up.poznan.pl

4 Department of Applied Chemistry, Faculty of Agriculture, University of South Bohemia, 370-04 České Budějovice, Czech Republic; kalac@zf.jcu.cz

5 Department of Environmental Medicine, Poznań University of Medical Sciences, Rokietnicka 8, 60-806 Poznań, Poland; rzymskipiotr@ump.edu.pl

6 Integrated Science Association (ISA), Universal Scientific Education and Research Network (USERN), Rokietnicka 8, 60-806 Poznań, Poland

7 Faculty of Chemistry, Adam Mickiewicz University in Poznań, Uniwersytetu Poznańskiego 8, 61-614 Poznań, Poland; pnied@amu.edu.pl

updates

Citation: Budzyńska, S.; Siwulski, M.; Magdziak, Z.; Budka, A.; Gąsecka, M.; Kalač, P.; Rzymski, P.; Niedzielski, P.; Mleczek, M. Influence of Iron Addition (Alone or with Calcium) to Elements Biofortification and Antioxidants in Pholiota nameko. Plants 2021, 10, 2275. https:// doi.org/10.3390/plants10112275

Academic Editor:

Pedro Diaz-Vivancos

Received: 3 October 2021

Accepted: 21 October 2021

Published: 24 October 2021

Publisher's Note: MDPI stays neutral with regard to jurisdictional claims in published maps and institutional affiliations.

Copyright: (c) 2021 by the authors. Licensee MDPI, Basel, Switzerland. This article is an open access article distributed under the terms and conditions of the Creative Commons Attribution (CC BY) license (https:// creativecommons.org/licenses/by/ $4.0 /)$.
* Correspondence: sylwia.budzynska@up.poznan.pl; Tel.: +48-61-8487846; Fax: +48-61-8487824

Abstract: Mushrooms supplementation with iron (Fe) is usually limited, and therefore it would be beneficial to search for other vital elements able to improve the process. The aim of this study was to verify a possible interaction between Fe and calcium (Ca) to estimate the role of the addition of the latter metal to stimulate Fe accumulation in Pholiota nameko. Additionally, an analysis of phenolic compounds and low molecular weight organic acids (LMWOAs) was performed. The increase of Fe concentration in the substrate caused a significantly higher accumulation of this metal in P. nameko. The addition of Ca (5 or $10 \mathrm{mM})$ stimulated Fe accumulation, just as Fe concentration in the substrate stimulated $\mathrm{Ca}$ accumulation, which pointed to a synergism between these metals. The obtained results show that the presence of Fe in the substrate may also promote $\mathrm{K}, \mathrm{Mg}, \mathrm{Mn}, \mathrm{Na}, \mathrm{P}$, and $S$ accumulation. In contrast, the addition of $C$ a stimulates and/or inhibits their content in fruit bodies. The phenolic and organic acids profile was poor. Only gallic, 4-hydroxybenzoic, sinapic and syringic acids (phenolics), as well as citric and succinic acids (LMWOAs), were quantified in some combinations in P. nameko fruiting bodies.

Keywords: metal interaction; functional food; iron deficiencies; mushroom supplementation

\section{Introduction}

Nowadays, no one doubts that our survival and health depends largely on the quality and safety of the food we eat. An imbalance between the macro and micronutrients required for metabolism reactions leads to malnutrition. One of its forms is undernutrition resulting from nutrient deficiencies (these terms are often incorrectly used interchangeably) [1]. Unfortunately, elemental deficiencies are still a relevant health issue in developing and underdeveloped countries [2]. The causes of undernutrition or even hidden hunger include deficiency of nutrients in soils, calcareous, or alkali reactions, mono-cropping in agriculture, insufficient quantitative and qualitative supply of food, as well as allergies and intolerances $[3,4]$.

A potentially nutrient improving intake strategy for enriching our diet with specific elements is food fortification [5]. Methods that offer meaningful solutions include classical, 
industrial, large-scale fortification and enhancement through genetic engineering $[4,6]$. Another approach is biofortification. This involves plant breeding and production to enhance the product's nutritional value by supplementing it with bioavailable nutrients present in the natural human diet in an inadequate amount [7].

One of the chemical elements characterized by a deficit due to low bioavailability is iron $(\mathrm{Fe})$. This element is a versatile transition metal found in almost all living organisms on Earth and one of the essential micronutrients required by plants and animals [8]. In humans, this fundamental trace element is used to synthesize heme, iron-sulfur containing proteins and other vital cofactors in many enzymes involved in respiration, redox reactions, catalysis, synthesis, and transcription of DNA. Unfortunately, although Fe is one of the most abundant elements, its availability is limited in soil. It exists mainly as insoluble ferric hydroxides and thus is bio-unavailable $[9,10]$. Hence, plants are a limited dietary Fe source, which is crucial because most people rely on plant-based foods as their primary metal source [8].

Iron deficiency (ID) is one of the leading contributors to the worldwide burden of disease. It mainly affects children, premenopausal women, and people in low- and middleincome countries [11]. It is one of the major nutritional problems worldwide as it affects approximately one-third of the world population. Fortification offers a chance to counteract this issue. Clinical studies have shown that consuming Fe-fortified foods is one of the most effective ways to prevent the element deficiency [12]. Therefore, there are many literature data on the production of food supplemented by Fe, for example, cereal [13], drinking water [14], yoghurt [15], and salt [16].

Nevertheless, the development of efficacious Fe-fortified dietary products has proven more challenging than developing nutritionally effective foods supplemented with other micronutrients. Unlike most other elements, Fe can cause unacceptable changes to foods. For example, the more bioavailable soluble compounds cause inappropriate colour and flavour changes, whereas less soluble Fe compounds cause less sensory changes but are much less well absorbed [17]. Therefore, it is essential to continuously innovate the processing technologies and novel ingredients for metal fortification. Mushrooms can be an interesting object of supplementation. They are attractive, healthy food because they are poor in calories and fat but rich in proteins, minerals, and dietary fibre. Promising anticarcinogenic, antigenotoxic, and immunomodulatory activities of polysaccharides and other macromolecules derived from mushrooms are another factor in their favour [18-20]. Due to their high element accumulation capacity, bio-enriched mushrooms can serve as food supplements rich in antioxidants and sources of macro- and micro-elements in fortified food production [21]. Additionally, the verification of potential interactions between the supplemented elements [22] seems to be an exciting issue that gives hope for increasing the efficiency of this process.

Given the above, we decided to look at the Fe fortification of Pholiota nameko. The species was selected for the most promising results for Fe supplementation during the preliminary experiment. The aim of this study was to determine the role of calcium (Ca) addition to Fe-fortification and verify a possible interaction between these elements in P. nameko fruit bodies with an analysis of phenolic compounds and low molecular weight organic acids (LMWOAs).

\section{Materials and Methods}

\subsection{Microorganisms and Spawn}

The PN04 strain of P. nameko was used in the experiment. The strain was obtained from the Mushroom Collection of Poznań University of Life Science (Department of Vegetable Crops). The spawn for inoculation of substrates was prepared by the method described by [23]. 


\subsection{Substrate Preparation}

A substrate derived from a mixture of alder and beech sawdust (1:1 vol.) for cultivation was used in the experiment. It was additionally supplemented with $20 \%$ wheat bran and $5 \%$ cornmeal. The substrate was mixed with LPM 20 stirrer (Glass, Germany) and moistened with Fe (iron (III) chloride hexahydrate) and Ca (calcium nitrate hydrate) salts dissolved in distilled water. The salts of both metals were used in this way to obtain final concentrations in the substrate, which were: 5,10 , and $15 \mathrm{mM}$ of $\mathrm{Fe}$ and 5 and $10 \mathrm{mM}$ of $\mathrm{Ca}$ in the following systems: Fe5, Fe10, Fe15, Fe5+Ca5, Fe10+Ca5, Fe15+Ca5, Fe5+Ca10, Fe10+Ca10, and Fe15+Ca10. As a control system, substrate without the addition of $\mathrm{Ca}$ and Fe salts was used.

After mixing with the solutions, the substrates had a humidity of $60 \%$. They were then placed in polypropylene bottles of $0.85 \mathrm{dm}^{3}$ volume. Each bottle was filled with $450 \mathrm{~g}$ of the substrate and closed with PP filter (class F-9, Filtropol, Poland). The substrates were sterilized at $121{ }^{\circ} \mathrm{C}$ for one hour, and next were cooled down to $25^{\circ} \mathrm{C}$, after which they were inoculated with $10 \mathrm{~g}$ of spawn (on wheat grain) for each bottle.

Incubation was conducted at a temperature of $25{ }^{\circ} \mathrm{C}$ and $80-85 \%$ air relative humidity for 30 days. The bottles with removed covers and bags were then placed in the cultivation room. For fructification, air relative humidity was maintained at $95-100 \%$ and temperature at $15 \pm 1{ }^{\circ} \mathrm{C}$. The cultivation was additionally lighted with fluorescent light of $500 \mathrm{~lx}$ intensity for $12 \mathrm{~h}$ a day. The growth room was aerated in such a way as to maintain $\mathrm{CO}_{2}$ concentration below $1000 \mathrm{ppm}$. Yield included whole fruit bodies. Depending on the combination, the pins appeared after 7-10 days, and the fruiting bodies grew to harvest within the next 5- 6 days. The fruiting bodies were harvested by twisting them out of the substrate (whole clump), and then the remnants of the substrate were removed. Whole fruiting bodies constituted the yield. Harvesting was performed when most of the fruiting bodies in a clump had a broken veil covering the gills, but the cap was not yet fully open. One flush of fruiting bodies was collected. The yield was calculated as the mean of five replicates. It was the mass per one bottle (i.e., $450 \mathrm{~g}$ of the substrate).

The growth of the mycelium was also studied using the same media. The substrates were filled in glass tubes $(18 \times 2 \mathrm{~cm})$ to a height of $15 \mathrm{~cm}$, sealed with cellulose plugs and then sterilized in the same conditions as those in bottles. The substrates were inoculated by placing a $1 \mathrm{~cm}$ layer of mycelium on wheat grains on the upper surface of the substrates. Incubation in tubes was carried out at $25^{\circ} \mathrm{C}$. The measure of mycelium growth was the layer of the substrate overgrown with hyphae after 28 days of incubation (see Figure 1).

\subsection{Studies on Total Concentration of Elements}

\subsubsection{Procedure}

The dry samples (dried at $45 \pm 5{ }^{\circ} \mathrm{C}$ in an electric oven Thermocenter, Salvislab, Switzerland) were accurately weighed $0.200-0.500 \mathrm{~g}( \pm 0.001 \mathrm{~g})$ and then digested by nitric acid (65\%; Sigma-Aldrich, St. Louis, MO, USA) in closed Teflon containers at $180^{\circ} \mathrm{C}(20 \mathrm{~min}$ ramp time, 20 min hold time, 20 min cooling downtime) in the microwave digestion system Mars 6 Xpress (CEM, Matthews, NC, USA). After digestion, samples were diluted with water (purified in MilliQ water purification system Millipore, Darmstadt, Germany) to a total volume of $15.0 \mathrm{~mL}$.

\subsubsection{Instrumentation}

The inductively coupled plasma high-resolution optical emission spectrometer ICPhrOES PlasmaQuant 9100 Elite (Analytik Jena, Jena, Germany) was used for calcium (Ca), iron $(\mathrm{Fe})$, magnesium $(\mathrm{Mg})$, sodium $(\mathrm{Na})$, potassium $(\mathrm{K})$, manganese $(\mathrm{Mn})$, phosphorus $(\mathrm{P})$, and sulphur (S) determination. Different wavelengths and plasma observations were used for low and high element concentrations (except Mn-Table S1). The common conditions were applied: axial plasma view for low and radial plasma view for high concentration, Radio Frequency (RF) power $1.20 \mathrm{~kW}$, plasma gas flow $12.0 \mathrm{~L} \mathrm{~min}^{-1}$, nebulizer gas flow $0.50 \mathrm{~L} \mathrm{~min}^{-1}$, auxiliary gas flow $0.5 \mathrm{~L} \mathrm{~min}^{-1}$, and sample flow rate $0.65 \mathrm{~mL} \mathrm{~min}^{-1}$; the 
signal was measured in five replicates during $1 \mathrm{~s}$ each. The calibration curves were constructed based on four points separately for the low and high concentrations of elements using different wavelengths (Table S1). Argon (Ar) was used as an internal standard (emission at wavelength $420.068 \mathrm{~nm}$ was controlled).

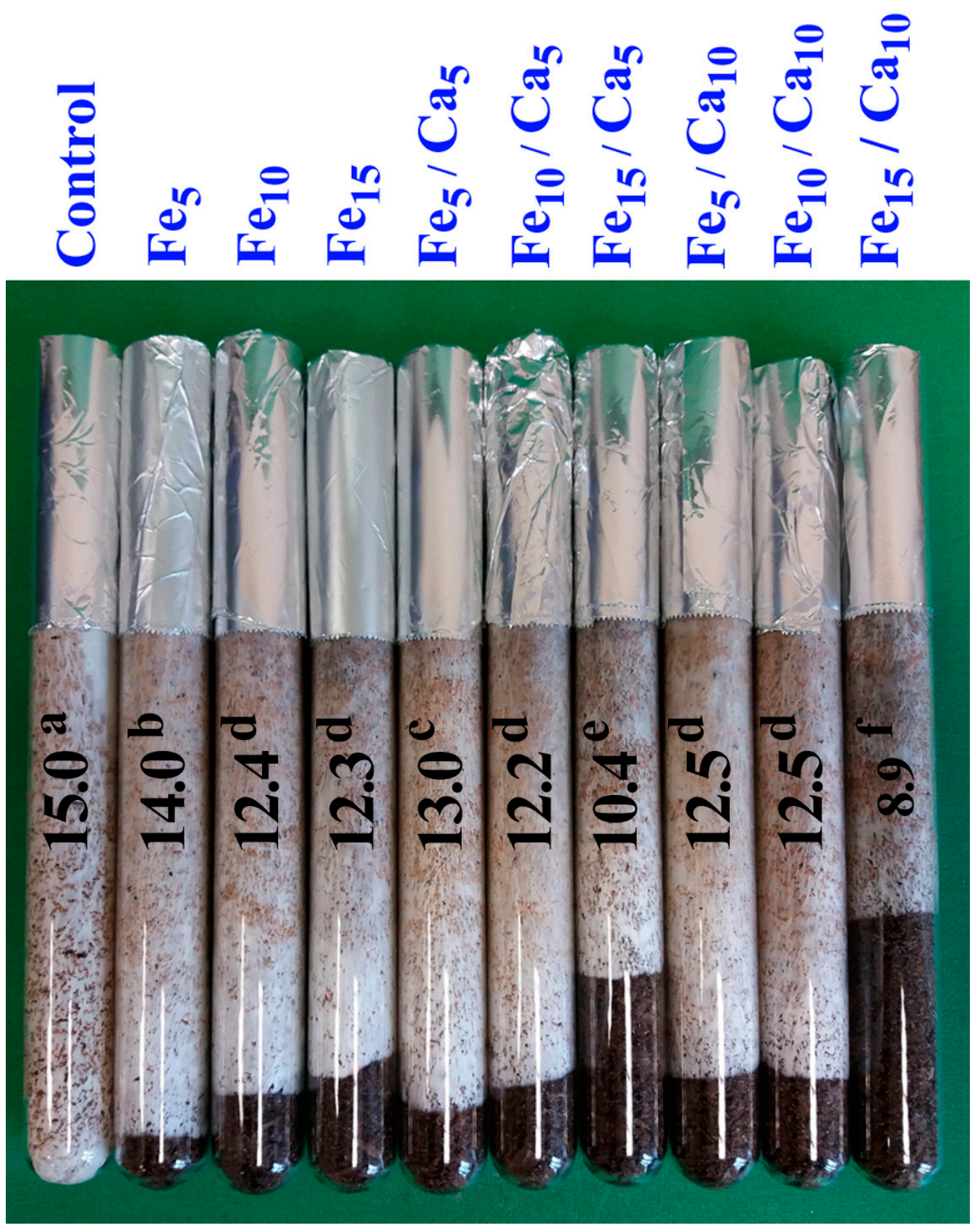

Figure 1. Characteristics of mycelium growth $(\mathrm{cm})$ for particular experimental systems. $n=5$, identical lower cases $(\mathrm{a}, \mathrm{b} \ldots$... ) denote non-significant differences between mean Pholiota nameko growth in particular experimental systems according to post-hoc Tukey's HSD test.

\subsubsection{Analytical Method Validation}

The detection limit was determined at the level of $0.01 \mathrm{mg} \mathrm{kg}^{-1}$ dry weight (DW) based on 3-sigma criteria (Table S1). Accuracy was checked by analysis of the reference materials NCSDC (73349)—bush branches and leaves; CRM S-1—loess soil; CRM 667-estuarine sediments; CRM 405-estuarine sediments; CRM 2709-soil; and the recovery (80-120\%) was acceptable. The uncertainty for the total analytical procedure (including sample preparation) was at the level of $20 \%$. 


\subsection{Determination of Phenolic Compounds and Organic Acids}

Phenolic compounds and organic acids were extracted from homogenized fruit bodies of $P$. nameko (5 g) using $80 \%$ ethanol ( $25 \mathrm{~g}$ ). The samples were sonicated at $40{ }^{\circ} \mathrm{C}$ for $20 \mathrm{~min}$ (Bandelin Sonorex RK 100, Berlin, Germany), shaken for $12 \mathrm{~h}$ at room temperature and then centrifuged at $2700 \mathrm{~g}$ for $15 \mathrm{~min}$ at $25^{\circ} \mathrm{C}$ (Universal 320R Hettich Zentrifugen, Tuttlingen, Germany) evaporated to dryness and stored at $-20{ }^{\circ} \mathrm{C}$ before analyses.

The determination was carried out using ultra-performance liquid chromatography, ACQUITY UPLC H-Class System (Waters Corp., Milford, MA, USA), with separation on an Acquity UPLC BEH C18 column $(2.1 \mathrm{~mm} \times 150 \mathrm{~mm}, 1.7 \mu \mathrm{m}$, Waters, Milford, MA, USA) thermostated at $35^{\circ} \mathrm{C}$. The mixture of water and acetonitrile (both containing $0.1 \%$ formic acid, $\mathrm{pH}=2$ ) at the flow rate of $0.4 \mathrm{~mL} \mathrm{~min}^{-1}$ with the gradient elution was used (flow $0.4 \mathrm{~mL} / \mathrm{min}-5 \%$ B (2 min), $5-16 \%$ B ( $5 \mathrm{~min}), 16 \%$ B (3 min), $16-20 \%$ B (7 min), $20-28 \%$ $B(11 \mathrm{~min}$ ) flow $0.45 \mathrm{~mL} / \mathrm{min}-28 \%$ (1 $\mathrm{min}), 28-60 \%$ B (3 min) flow $5.0 \mathrm{~mL} / \mathrm{min}-60-95 \%$ $\mathrm{B}(1 \mathrm{~min}), 65 \% \mathrm{~B}(1 \mathrm{~min})$, and $95-5 \% \mathrm{~B}(0.1 \mathrm{~min})$ flow $0.4 \mathrm{~mL} / \mathrm{min}-5 \% \mathrm{~B}(1.9 \mathrm{~min})$ and the injection volume was $5 \mu \mathrm{L}$. The identification of peaks was based on a comparison with the retention times of chemical standards. The Waters Photodiode Array Detector (Waters Corporation, Milford, MA, USA) was applied for the detection of individual components at $\lambda=280 \mathrm{~nm}$ and $\lambda=320 \mathrm{~nm}$ [24].

\subsection{Determination of Total Phenolic (TP) Content}

A mixture of $200 \mu \mathrm{L}$ of the extracts and $1 \mathrm{~mL}$ of Folin-Ciocalteu reagent (diluted with deionized water v:v (1:1) was incubated for $3 \mathrm{~min}$, then $1 \mathrm{~mL}$ of $20 \% \mathrm{Na}_{2} \mathrm{CO}_{3}$ was added. The samples were kept in darkness for $30 \mathrm{~min}$ at room temperature. The absorbance of the samples was measured at $765 \mathrm{~nm}$ using a UV-spectrophotometer. Gallic acid was used as the standard for TP content quantification. The concentration of total phenolic content (TP) was expressed as milligram gallic acid equivalents per dried weight (mg GAE $\left.\cdot \mathrm{g}^{-1} \mathrm{DW}\right)$. Gallic acid was used as the standard for TP quantification [25].

\subsection{Statistical Analysis}

Statistical analyses were performed using the agricole package (R) (Bell Laboratories). To compare mean content of elements, phenols, and LMWOAs in P. nameko growing in particular experimental systems, one-dimensional analysis of variance (ANOVA), and finally, the multiple comparisons Tukey's HSD test were performed, which allowed the existence of the uniform groups of objects to be shown $(\alpha=0.05)$. For a graphical presentation of the relationships between particular objects ( $P$. nameko fruit bodies in experimental systems) due to the content of elements, phenols, and LMWOAs, Principal Component Analysis (PCA) was performed [26]. Heatmaps were prepared to show similarities/differences between mushrooms in particular experimental systems regarding all elements, antioxidants, and studied parameters jointly [27]. All data on chemical elements' content in the text and tables are given in $\mathrm{mg} \mathrm{kg}^{-1} \mathrm{DW}$. For each condition and analysis, five replicates were determined.

\section{Results}

\subsection{Mycelium Growth and Mushroom Yield}

The mycelium in the control grew the fastest. In each case, when the addition of Fe and Ca was applied, the mycelium grew more slowly. However, it was found that inhibition of mycelium growth depended on the dose of Fe and Ca. The mycelium grew the most slowly with the addition of $\mathrm{Fe}$ and $\mathrm{Ca}$ in the highest concentration. In this case, the synergistic effect of these metals was noticeable. It was found that the higher the Fe dose, the slower the mycelial growth was (Figure 1).

The addition of Fee alone or in combinations with Ca led to the negative effect on the weight (amount) of the fruiting bodies (on yield). Fe (5 and $10 \mathrm{mM}$ ) did not cause a significant decrease of yield (76.0 and $69.9 \mathrm{~g}$, respectively) concerning the control (78.7 g) (Figure 2). However, the addition of $15 \mathrm{mM}$ of Fe led to a significant decrease in 
P. nameko yield (47.9 g). A similar tendency was observed for the rest of the experimental systems, where under 5 or $10 \mathrm{mM}$ of $\mathrm{Ca}$, the addition of 5 (64.4 and $56.7 \mathrm{~g}$, respectively) or 10 (54.0 and $44.5 \mathrm{~g}$, respectively) $\mathrm{mM}$ of Fe a similar yield was observed, becoming significantly higher than after $15 \mathrm{mM}$ of Fe and 5 or $10 \mathrm{mM}$ of Ca addition (44.5 and $17.6 \mathrm{~g}$, respectively). The general decrease in the fruit body yield was not accompanied by any changes in their colour and only slight modifications in cap shape (Figure 3).

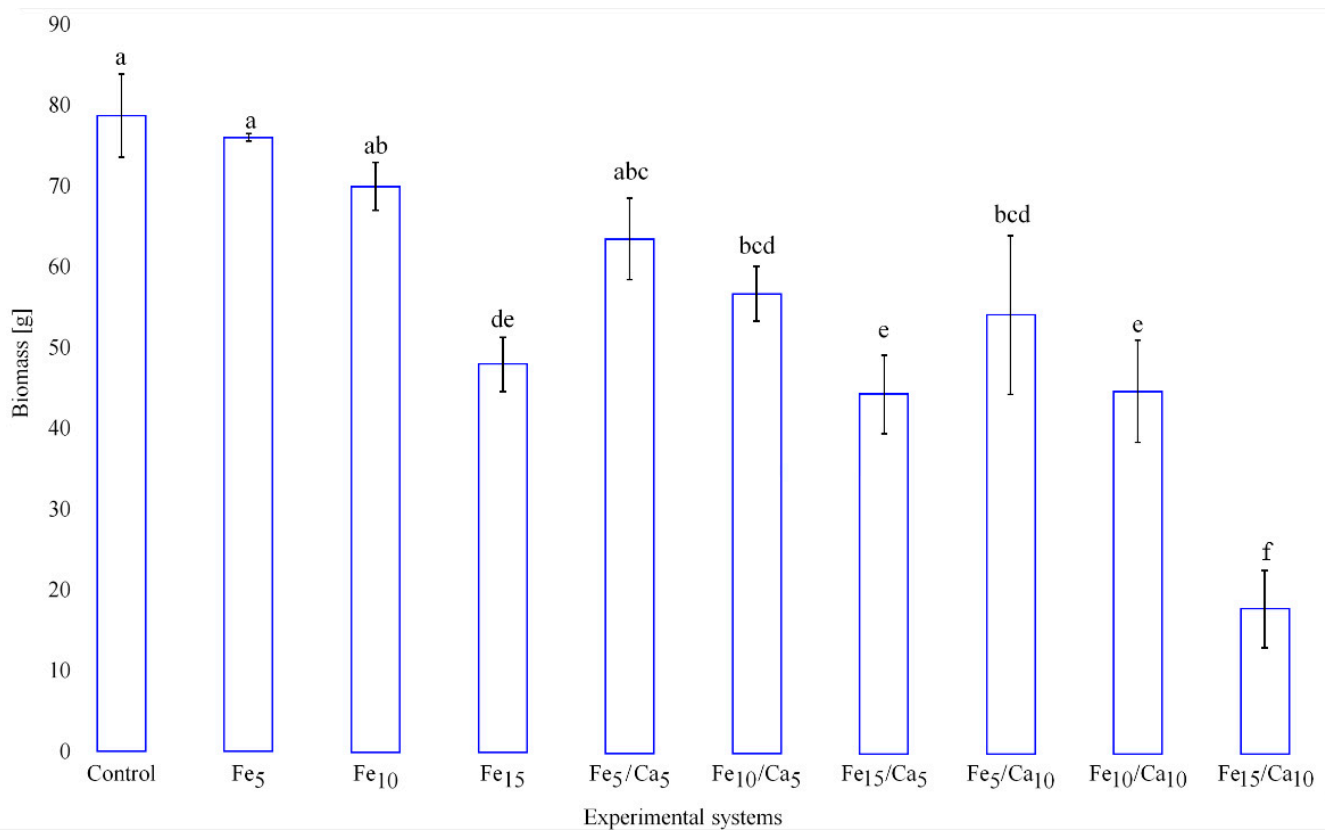

Figure 2. Yield (g) of Pholiota nameko exposed to particular experimental systems. $n=5$, identical lower cases $(\mathrm{a}, \mathrm{b}$... ) denote non-significant differences between mean Pholiota nameko yield growing in particular experimental systems according to post-hoc Tukey's HSD test.

\subsection{Mineral Composition of Mushroom Bodies}

\subsubsection{Content of Iron and Calcium}

The average content of Fe in the control P. nameko was significantly lower $\left(8.61 \mathrm{mg} \mathrm{kg}^{-1}\right)$ than after the addition of this metal to the substrate $(5,10$ and $15 \mathrm{mM})$. It was: $15.9,19.8$ and $25.1 \mathrm{mg} \mathrm{kg}^{-1}$, respectively (Figure 4a). The addition of $5 \mathrm{mM}$ of Ca to the substrate caused a significantly higher accumulation of $\mathrm{Fe}\left(23.1,24.7\right.$, and $31.6 \mathrm{mg} \mathrm{kg}^{-1}$, respectively for $\mathrm{Fe}_{5} \mathrm{Ca}_{5}, \mathrm{Fe}_{10} \mathrm{Ca}_{5}$, and $\mathrm{Fe}_{15} \mathrm{Ca}_{5}$ ) (Table S2). It is worth underlining that the addition of $10 \mathrm{mM}$ of Ca to $15 \mathrm{mM}$ of Fe caused the highest accumulation of this metal $\left(38.3 \mathrm{mg} \mathrm{kg}^{-1}\right)$, which was clearly observed in PCA analysis, where $61.99 \%(36.47+25.52)$ of total variability was explained.

The content of $\mathrm{Ca}$ in the control variant of P. nameko and the $\mathrm{Fe}_{5}, \mathrm{Fe}_{10}$ and $\mathrm{Fe}_{15}$ experimental systems was almost the same $\left(233,241,219\right.$, and $225 \mathrm{mg} \mathrm{kg}^{-1}$, respectively) (Figure $4 \mathrm{~b}$ ). The addition of $5 \mathrm{mM}$ of $\mathrm{Ca}$ and an increase of Fe content in the substrate $\left(\mathrm{Fe}_{5} \mathrm{Ca}_{5}, \mathrm{Fe}_{10} \mathrm{Ca}_{5}\right.$, and $\left.\mathrm{Fe}_{15} \mathrm{Ca}_{5}\right)$ was related to significantly higher $\mathrm{Ca}$ content than in the control (458, 698, and $931 \mathrm{mg} \mathrm{kg}^{-1}$, respectively). Moreover, the addition of $10 \mathrm{mM}$ of Ca caused an even higher accumulation of Ca $\left(825,1430\right.$, and $1630 \mathrm{mg} \mathrm{kg}^{-1}$, respectively), also confirmed by PCA analysis, where Ca was situated between $\mathrm{Fe}_{10} \mathrm{Ca}_{10}$ and $\mathrm{Fe}_{15} \mathrm{Ca}_{10}$. The obtained results indicate that the mutual interaction between these metals and their concentration in the substrate affects their accumulation in P. nameko fruit bodies. 


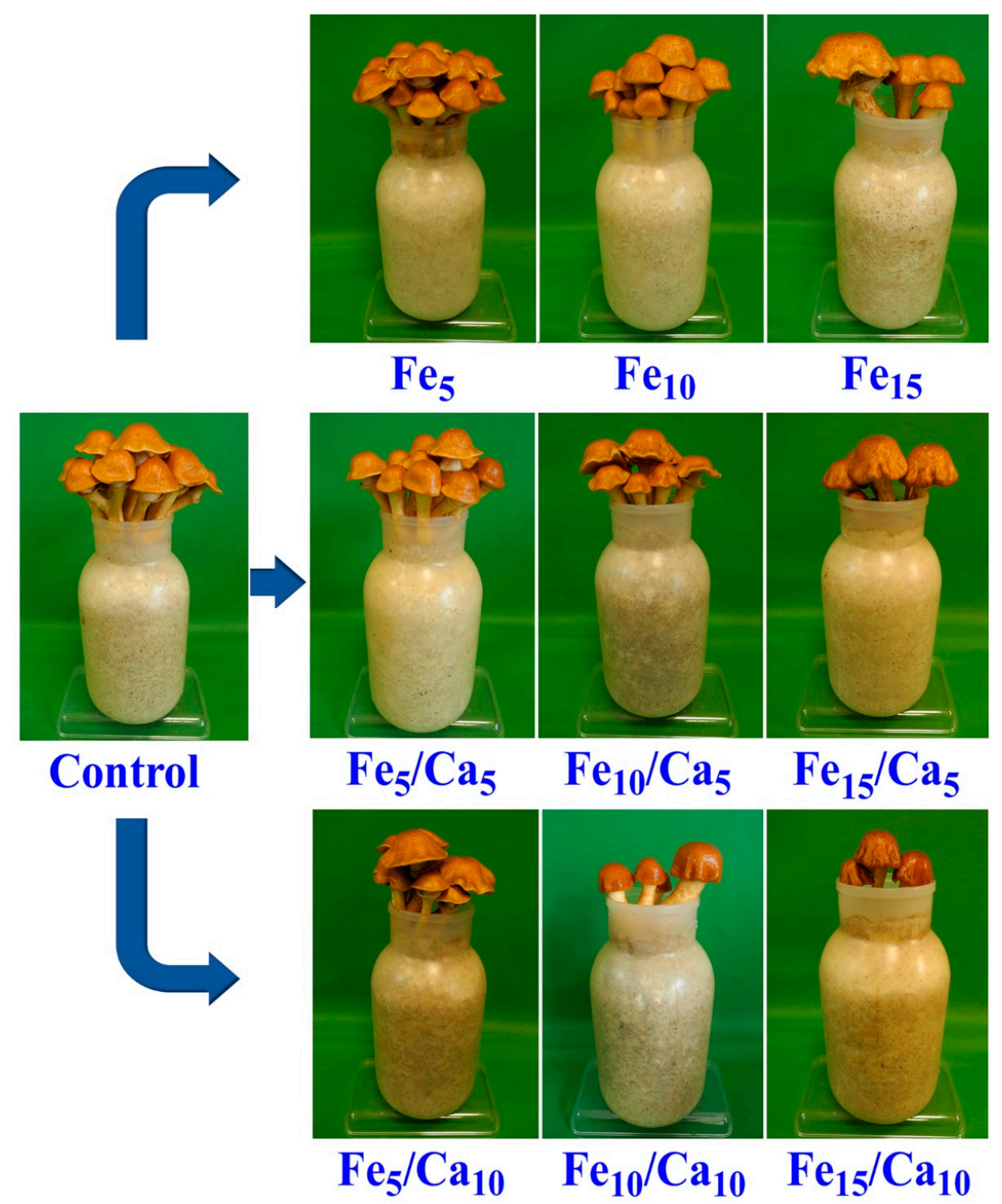

Figure 3. Macroscopic characteristics of Pholiota nameko exposed to particular experimental systems.

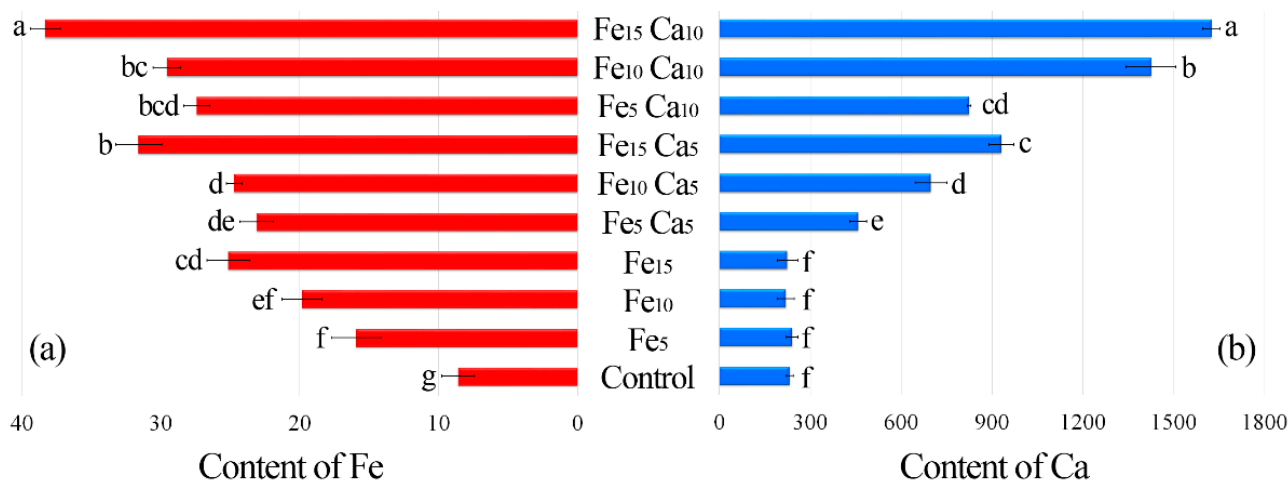

Figure 4. Content of $\mathrm{Fe}(\mathbf{a})$ and $\mathrm{Ca}(\mathbf{b})\left(\mathrm{mg} \mathrm{kg}^{-1} \mathrm{DW}\right)$ in mushrooms exposed to particular experimental systems. $n=6$, identical lower cases $(\mathrm{a}, \mathrm{b} \ldots$ ) denote non-significant differences between mean content of $\mathrm{Ca}$ or $\mathrm{Fe}$ in Pholiota nameko fruit bodies growing in particular experimental systems according to post-hoc Tukey's HSD test. 


\subsubsection{Content of Other Elements}

The addition of $15 \mathrm{mM}$ of Fe only significantly influenced higher $\mathrm{K}$ accumulation by P. nameko fruit bodies than the control (19,100, and $11,300 \mathrm{mg} \mathrm{kg}^{-1}$, respectively) (Figure 5a). The addition of $\mathrm{Ca}$ ( 5 or $10 \mathrm{mM}$ ) did not lead to a significantly higher/lower content of $\mathrm{K}$ in mushrooms compared to the control. Increasing the Fe concentration in substrate stimulated $\mathrm{Mg}$ accumulation by $P$. nameko bodies $\left(651,852\right.$, and $928 \mathrm{mg} \mathrm{kg}^{-1}$, respectively, for the $\mathrm{Fe}_{5}, \mathrm{Fe}_{10}$, and $\mathrm{Fe}_{15}$ systems), similarly to the presence of $\mathrm{Ca}(5 \mathrm{mM})(614,870$, and $937 \mathrm{mg} \mathrm{kg}^{-1}$, respectively, for the $\mathrm{Fe}_{5} \mathrm{Ca}_{5}, \mathrm{Fe}_{10} \mathrm{Ca}_{5}$, and $\mathrm{Fe}_{15} \mathrm{Ca}_{5}$ systems) (Table S2). Content of $\mathrm{Mg}$ in mushrooms growing in substrate enriched with $10 \mathrm{mM}$ of Ca was significantly higher than for control and almost the same independently of Fe addition $\left(724,709\right.$, and $728 \mathrm{mg} \mathrm{kg}^{-1}$, respectively for the $\mathrm{Fe}_{5} \mathrm{Ca}_{10}, \mathrm{Fe}_{10} \mathrm{Ca}_{10}$, and $\mathrm{Fe}_{15} \mathrm{Ca}_{10}$ systems) (Figure 5b). The content of $\mathrm{Mn}$ in control mushrooms was $6.71 \mathrm{mg} \mathrm{kg}^{-1}$, while the addition of Fe or Fe $+\mathrm{Ca}$ significantly stimulated the accumulation of this metal (Figure 5c). The highest content of $\mathrm{Mn}$ in mushrooms growing under the $\mathrm{Fe}_{10} \mathrm{Ca}_{10}$ and $\mathrm{Fe}_{15} \mathrm{Ca}_{10}$ systems was determined (29.5 and $28.2 \mathrm{mg} \mathrm{kg}^{-1}$, respectively) and clearly visible in the PCA analysis (Figure 6).

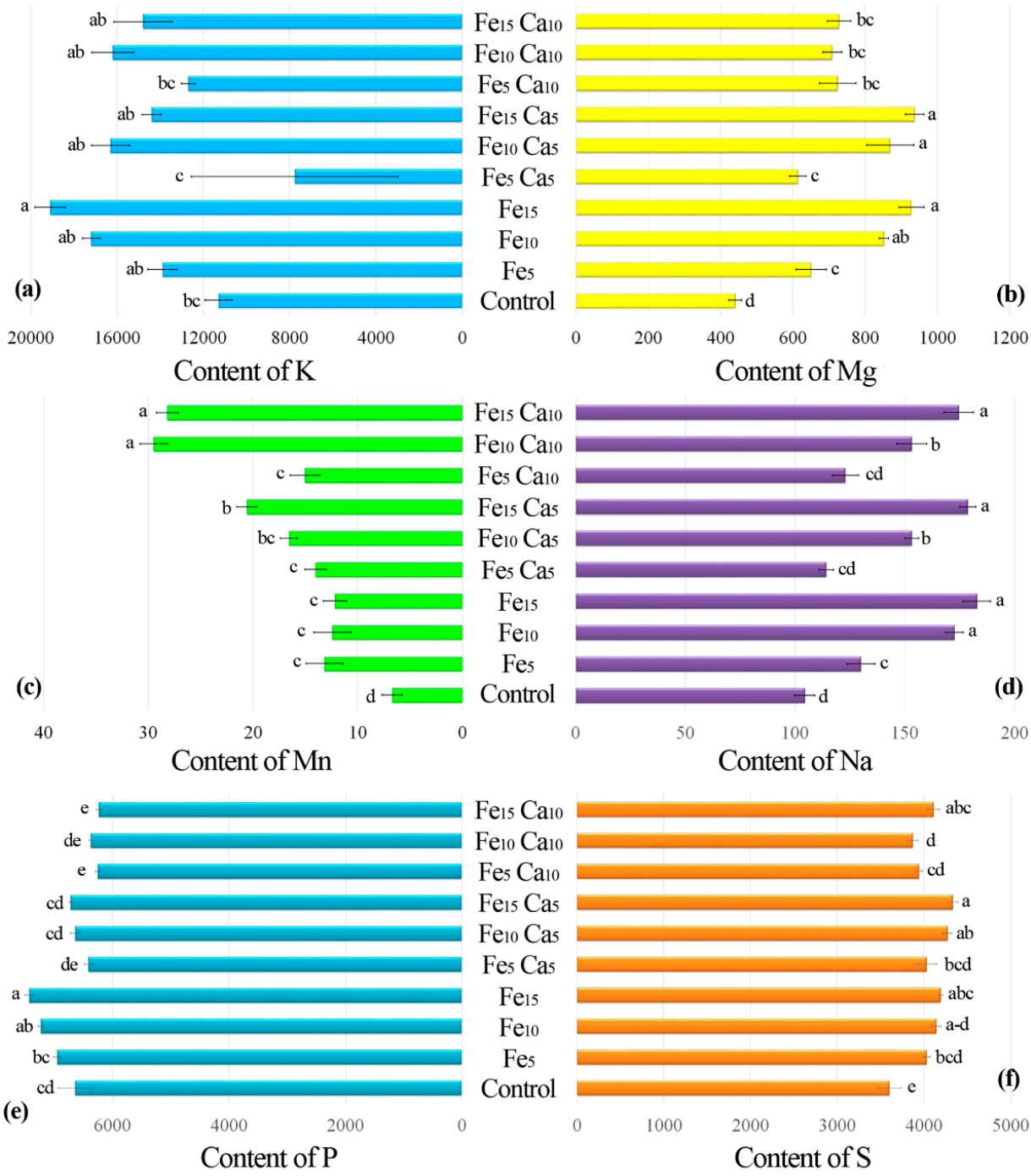

Figure 5. Content of $\mathrm{K}(\mathbf{a}), \mathrm{Mg}(\mathbf{b}), \mathrm{Mn}(\mathbf{c}), \mathrm{Na}(\mathbf{d}), \mathrm{P}(\mathbf{e})$, and $\mathrm{S}(\mathbf{f})\left(\mathrm{mg} \mathrm{kg}^{-1} \mathrm{DW}\right)$ in mushrooms exposed to particular experimental systems. $n=5$, identical lower cases $(\mathrm{a}, \mathrm{b} \ldots)$ denote nonsignificant differences between mean content of particular metals in Pholiota nameko fruit bodies growing in particular experimental systems according to post-hoc Tukey's HSD test. 


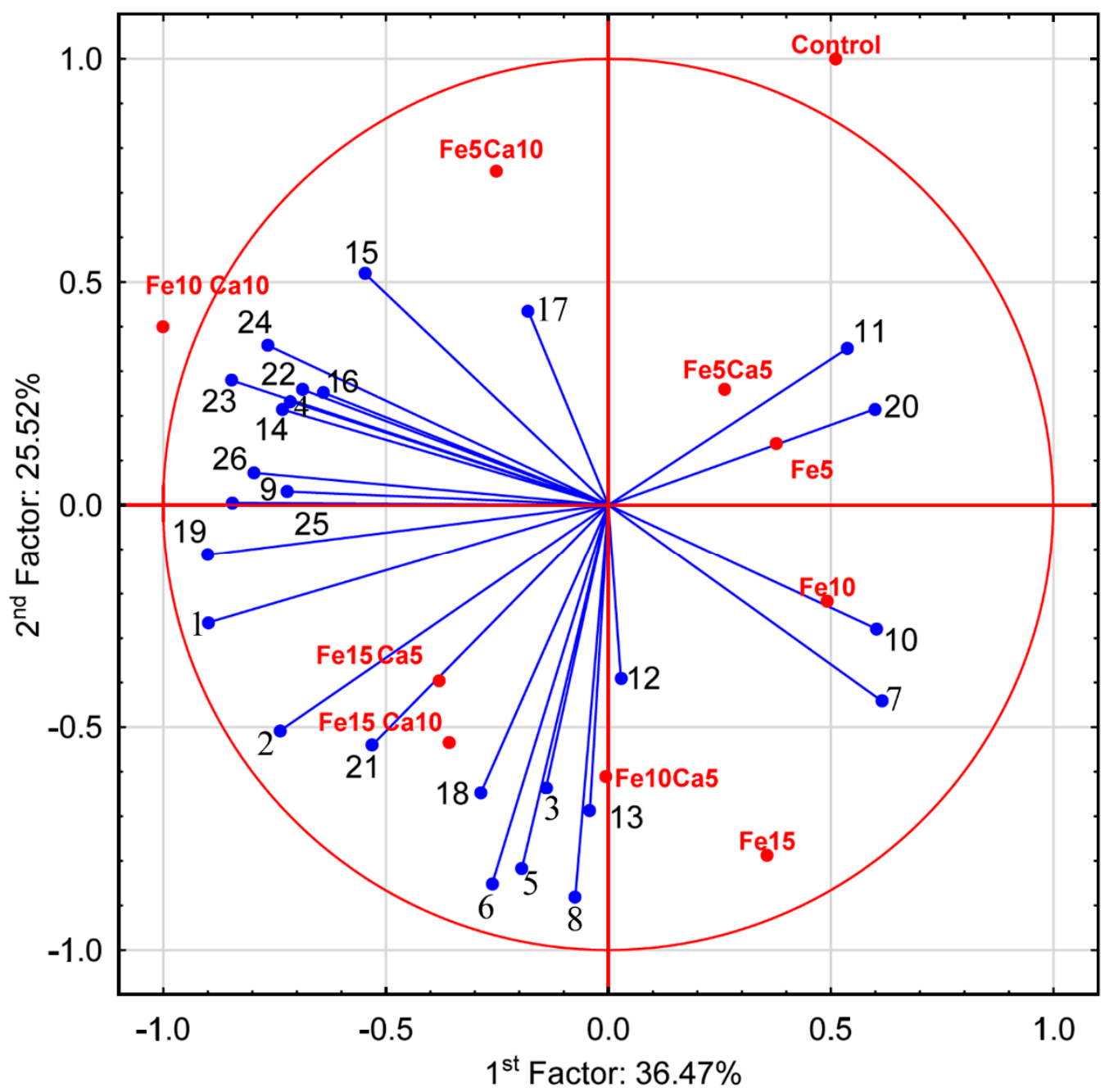

Figure 6. Principal Component Analysis for parameters characterizing mushrooms exposed to particular experimental systems. 1-Ca; 2-Fe; 3-K; 4-Mg; 5-Mn; 6-Na; 7-P; 8-S; 9-protocatechuic; 10-4-hydroxybenzoic acid; 11-catechin; 12-vanillic acid; 13-syringic acid; 14-2,5 dihydroxybenzoic acid; 15-caffeic acid; 16-chlorogenic acid; 17-sinapic acid; 18-TP; 19-quinic acid; 20-malic acid; 21-lactic acid; 22-citric acid; 23-acetic acid; 24-fumaric acid; 25-succinic acid; and 26-sum of LMWOAs.

Interesting results were observed for Na content in mushrooms (Figure $5 \mathrm{~d}$ ). Control P. nameko contained $104 \mathrm{mg} \mathrm{kg}^{-1}$, similar to $\mathrm{Fe}_{5} \mathrm{Ca}_{5}$ and $\mathrm{Fe}_{5} \mathrm{Ca}_{10}$ (114 and $123 \mathrm{mg} \mathrm{kg}^{-1}$, respectively). The addition of 5, 10, and $15 \mathrm{mM}$ of Fe caused a significantly higher content of $\mathrm{Na}$ in mushrooms than for the control (130,173, and $183 \mathrm{mg} \mathrm{kg}^{-1}$, respectively). The presence of $\mathrm{Ca}(5$ or $10 \mathrm{mM})$ did not influence $\mathrm{Na}$ accumulation except for $\mathrm{Fe}_{10} \mathrm{Ca}_{5}$ and $\mathrm{Fe}_{10} \mathrm{Ca}_{10}$, where a significantly lower content of $\mathrm{Na}$ was determined $\left(153 \mathrm{mg} \mathrm{kg}^{-1}\right.$ for both systems) than in mushrooms exposed to the $\mathrm{Fe}_{10}$ system $\left(173 \mathrm{mg} \mathrm{kg}^{-1}\right.$ ) (Table S2).

Pholiota nameko growing in substrate enriched with 10 or $15 \mathrm{mM}$ of Fe contained a significantly higher amount of $\mathrm{P}$ (7230 and $7430 \mathrm{mg} \mathrm{kg}^{-1}$, respectively) than in the control $\left(6640 \mathrm{mg} \mathrm{kg}^{-1}\right.$ ) (Figure 5e). The addition of $5 \mathrm{mM}$ of Ca to substrate did not influence $\mathrm{P}$ content in fruit bodies, while the addition of $10 \mathrm{mM}$ of Ca inhibited $\mathrm{P}$ accumulation in two experimental systems $\left(\mathrm{Fe}_{5} \mathrm{Ca}_{10}\right.$ and $\left.\mathrm{Fe}_{15} \mathrm{Ca}_{10}\right)$ (Table S2). The growth of mushrooms in substrate enriched with $\mathrm{Fe}$ or $\mathrm{Fe}+\mathrm{Ca}$ caused a significantly higher content of $\mathrm{S}$ than in the control $\left(3600 \mathrm{mg} \mathrm{kg}^{-1}\right)$. The highest content of $S$ was recorded in P. nameko growing under $\mathrm{Fe}_{15} \mathrm{Ca}_{5}, \mathrm{Fe}_{10} \mathrm{Ca}_{5}, \mathrm{Fe}_{15} \mathrm{Ca}_{10}$, and $\mathrm{Fe}_{15}$ (4330, 4270, 4110, and $4190 \mathrm{mg} \mathrm{kg}{ }^{-1}$, respectively) (Figure 5f). 
A heatmap was prepared to show the similarity between P. nameko fruit bodies growing in a particular experimental system (Figure 7). Generally, three groups of objects were identified: 1st) Control, $\mathrm{Fe}_{5}, \mathrm{Fe}_{5} \mathrm{Ca}_{5}$, and $\mathrm{Fe}_{5} \mathrm{Ca}_{10}$; 2nd) $\mathrm{Fe}_{10} \mathrm{Ca}_{10}$ and $\mathrm{Fe}_{15} \mathrm{Ca}_{10}$; and 3rd) $\mathrm{Fe}_{10}, \mathrm{Fe}_{15}, \mathrm{Fe}_{10} \mathrm{Ca}_{5}$, and $\mathrm{Fe}_{15} \mathrm{Ca}_{5}$ with a similarity between the last two groups. The obtained results pointed to the significant role of $\mathrm{Fe}$ and $\mathrm{Ca}$ addition concerning the content of all determined elements jointly. Moreover, a lower addition of Fe and $\mathrm{Ca}$ in the substrate influenced the generally lower content of other elements. In contrast, mushroom exposure to higher contents of Fe and Ca tended to have the opposite effect.

\section{Data transformation using 'normalize'}
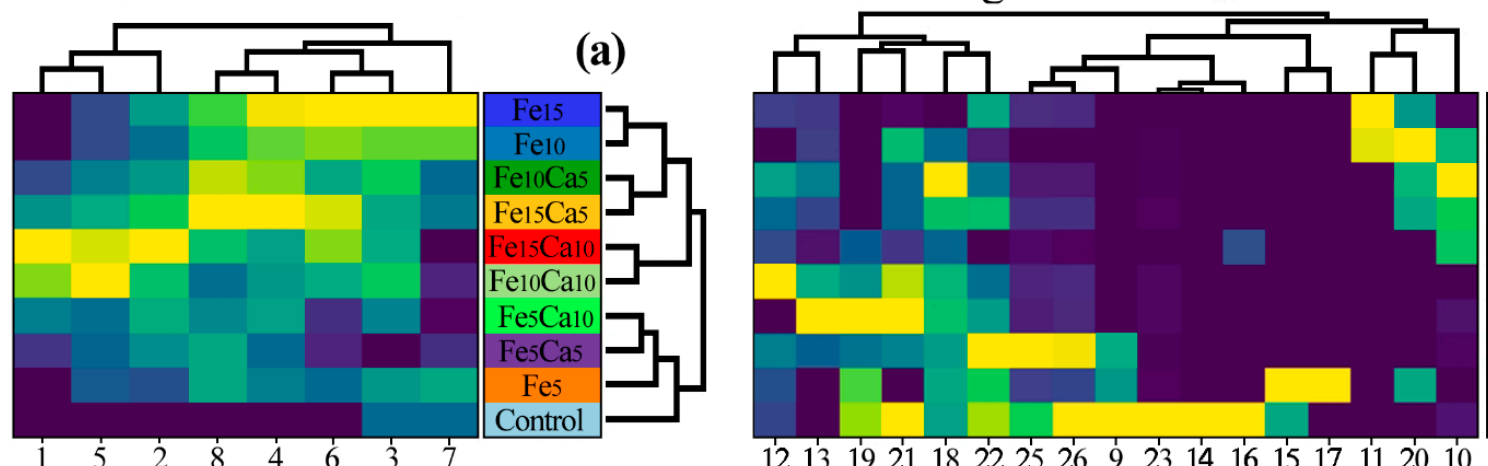

(b) $\begin{array}{lllllllllllllllll}12 & 13 & 19 & 21 & 18 & 22 & 25 & 26 & 9 & 23 & 14 & 16 & 15 & 17 & 11 & 20 & 10\end{array}$

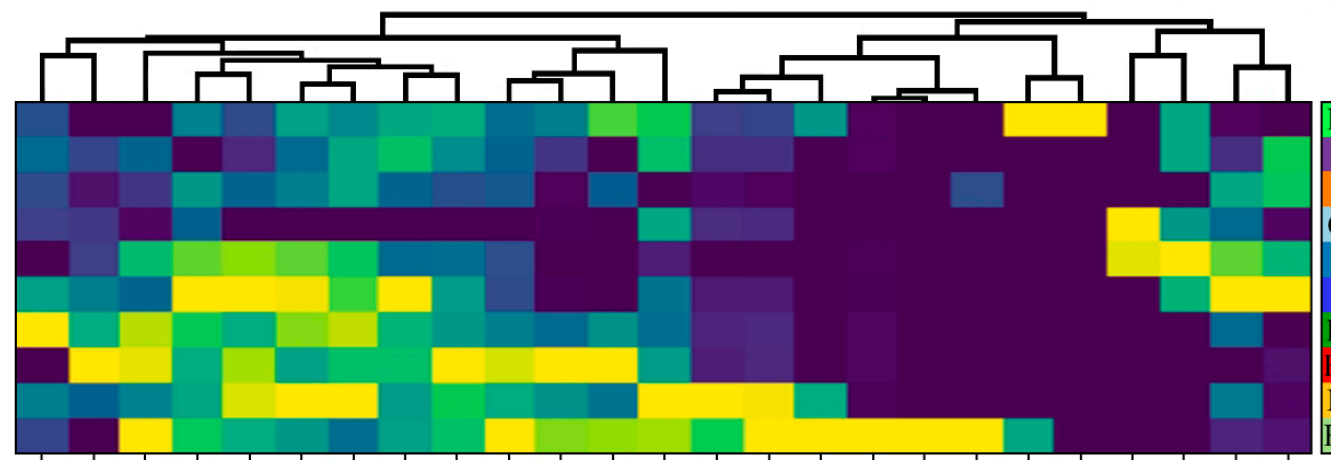

(c)
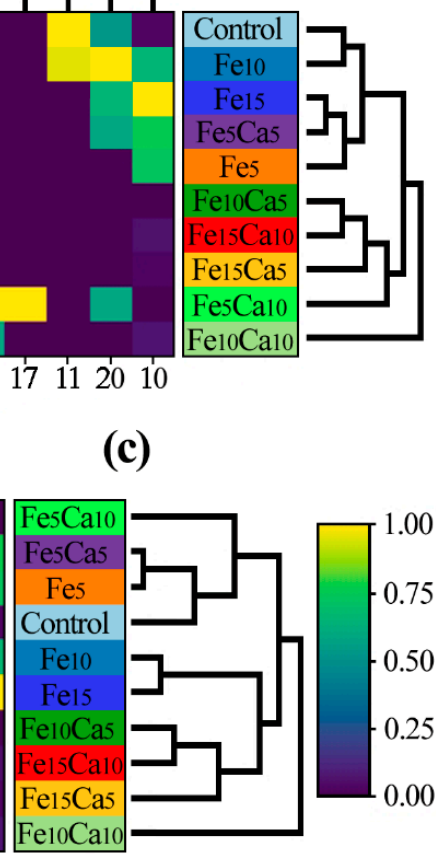

$\begin{array}{lllllllllllllllllllllllll}12 & 13 & 21 & 3 & 6 & 4 & 8 & 18 & 2 & 5 & 1 & 19 & 22 & 25 & 26 & 9 & 23 & 14 & 16 & 15 & 17 & 11 & 20 & 7 & 10\end{array}$

Parameters

Figure 7. Correlation between particular Pholiota nameko of all experimental systems concerning the content of (a) studied elements, (b) antioxidants, and (c) all studied parameters (Heatmap) in mean values with presentation of a hierarchical tree plot. 1-Ca; 2-Fe; 3-K; 4- Mg; 5-Mn; 6-Na; 7-P; 8-S; 9-protocatechuic; 10-4-hydroxybenzoic acid; 11-catechin; 12-vanillic acid; 13-syringic acid; 14-2,5 dihydroxybenzoic acid; 15-caffeic acid; 16-chlorogenic acid; 17-sinapic acid; 18-TP; 19-quinic acid; 20-malic acid; 21-lactic acid; 22-citric acid; 23-acetic acid; 24-fumaric acid; 25-succinic acid; and 26-sum of LMWOAs.

\subsection{Profile of Phenolic Compounds}

The profile of phenolic compounds varied in all combinations (Table 1). The lowest and highest content of phenolic compounds was confirmed for syringic acid in the control and $\mathrm{Fe}_{15} \mathrm{Ca}_{10}$, respectively ( 9.18 and $50.8 \mu \mathrm{g} \mathrm{g}^{-1} \mathrm{DW}$ ).

In the control, only gallic and syringic acids were identified. The most distinct phenolic acid profile was observed for mushrooms cultivated on the substrate with Fe and addition $\mathrm{Fe}_{5} \mathrm{Ca}_{5}$. In comparison to the control, 4-hydroxybenzoic acid (4-HBA) was detected in mushrooms cultivated in $\mathrm{Fe}$ and $\mathrm{Fe}_{5} \mathrm{Ca}_{5}$-supplemented substrates. Gallic acid was quantified in the control and mushrooms cultivated in $\mathrm{Fe}$ and $\mathrm{Fe}_{5} \mathrm{Ca}_{5}$-enriched substrates. Sinapic acid was detected only for $\mathrm{Fe}_{5} \mathrm{Ca}_{10}$, while syringic was found in almost all combinations. The simultaneous supplementation of the substrate with Fe and Ca in most combinations did not result in the detection of 4-HBA and gallic acid with the significant increase of syringic acid content. 
Table 1. Content ( $\left.\mu \mathrm{g} \mathrm{g}^{-1} \mathrm{DW}\right)$ of phenolic compounds.

\begin{tabular}{|c|c|c|c|c|c|}
\hline System & 4-HBA & Gallic & Sinapic & Syringic & $\mathrm{TP}\left[\mathrm{mg} \mathrm{g}^{-1} \mathrm{GAE}^{*}\right]$ \\
\hline Control & $\mathrm{bDL}$ & $14.8^{\mathrm{ab}}$ & $\mathrm{bDL}$ & $9.18^{\mathrm{e}}$ & $0.810^{\mathrm{e}}$ \\
\hline $\mathrm{Fe}_{5}$ & $27.6^{\mathrm{d}}$ & $11.1^{\mathrm{c}}$ & $\mathrm{bDL}$ & $\mathrm{bDL}$ & $1.02 \mathrm{de}$ \\
\hline $\mathrm{Fe}_{10}$ & $24.9^{\mathrm{c}}$ & $13.0 \mathrm{bc}$ & $\mathrm{bDL}$ & 11.7 de & 1.03 cde \\
\hline $\mathrm{Fe}_{15}$ & $37.5^{b}$ & $13.4^{b c}$ & $\mathrm{bDL}$ & $21.8^{c}$ & $1.44^{\mathrm{a}}$ \\
\hline $\mathrm{Fe}_{5} \mathrm{Ca}_{5}$ & $43.2^{\mathrm{a}}$ & $17.9^{\mathrm{a}}$ & $\mathrm{bDL}$ & $11.1^{\mathrm{e}}$ & $1.26^{\mathrm{ab}}$ \\
\hline $\mathrm{Fe}_{10} \mathrm{Ca}_{5}$ & $\mathrm{bDL}$ & $\mathrm{bDL}$ & $\mathrm{bDL}$ & $31.7^{b}$ & $1.22^{\mathrm{a}-\mathrm{d}}$ \\
\hline $\mathrm{Fe}_{15} \mathrm{Ca}_{5}$ & $\mathrm{bDL}$ & $\mathrm{bDL}$ & $\mathrm{bDL}$ & $15.5^{\mathrm{d}}$ & $1.16^{\mathrm{bcd}}$ \\
\hline $\mathrm{Fe}_{5} \mathrm{Ca}_{10}$ & $\mathrm{bDL}$ & $\mathrm{bDL}$ & 1.78 & $\mathrm{bDL}$ & $1.19 \mathrm{bcd}$ \\
\hline $\mathrm{Fe}_{10} \mathrm{Ca}_{10}$ & $\mathrm{bDL}$ & $\mathrm{bDL}$ & $\mathrm{bDL}$ & bDL & $1.17^{\mathrm{bcd}}$ \\
\hline $\mathrm{Fe}_{15} \mathrm{Ca}_{10}$ & $\mathrm{bDL}$ & $\mathrm{bDL}$ & $\mathrm{bDL}$ & $50.8^{a}$ & $1.25^{\mathrm{abc}}$ \\
\hline
\end{tabular}

* GAE-gallic acid equivalent; $n=5$; identical superscripts in columns denote no significant differences between means according to a post-hoc Tukey's HSD test at $\alpha=95 \%$ following one-way ANOVA, bDL-below detection limit, 4-HBA-4-hydroxybenzoic acid, and TP-total phenolic.

TP content was significantly affected by the supplementation of substrates. The lowest TP content, $0.81 \mathrm{mg} \mathrm{g}^{-1} \mathrm{GAE}$, was found in the control. The addition of Fe to substrate resulted in a significant increase of TP up to $1.44 \mathrm{mg} \mathrm{g}^{-1} \mathrm{GAE}$ as the higher content for $\mathrm{Fe}_{15}$. The supplementation of the substrate by Fe and $\mathrm{Ca}$ also increased TP content in comparison to the control. However, no significance in TP content was confirmed in any samples supplemented with Fe and Ca.

\subsection{Profile of Low Molecular Weight Organic Acids}

The profile and content of low molecular weight organic acids in the present experiment was very poor (Table 2). In general, only citric and succinic acids were identified in P. nameko fruiting bodies. The addition of Fe to the substrate $\left(\mathrm{Fe}_{5}, \mathrm{Fe}_{10}\right.$, and $\mathrm{Fe}_{15}$ systems) only caused the creation of succinic acid in P. nameko bodies, and at a lower content compared to the control. Additionally, compared to the control, the fruiting bodies did not contain citric acid. For the $\mathrm{Fe}_{5} \mathrm{Ca}_{10}, \mathrm{Fe}_{10} \mathrm{Ca}_{10}$, and $\mathrm{Fe}_{15} \mathrm{Ca}_{5}$, systems, where $\mathrm{Ca}$ and Fe were added simultaneously, the amount of succinic acids observed significantly increased (8.83, 28.6, and $36.4 \mu \mathrm{g} \mathrm{g}^{-1} \mathrm{DW}^{1}$, respectively) and the creation of citric acid was stimulated in P. nameco fruit bodies $\left(1.30,1.47\right.$, and $1.63 \mu \mathrm{g} \mathrm{g}^{-1} \mathrm{DW}^{1}$, respectively). In addition, acetic acid was determined in the $\mathrm{Fe}_{10} \mathrm{Ca}_{10}$ system, while it was below the detection level for the other systems.

Table 2. Content ( $\left.\mu \mathrm{g} \mathrm{g}^{-1} \mathrm{DW}\right)$ of low molecular weight organic acids.

\begin{tabular}{ccccc}
\hline System & Acetic & Citric & Succinic & Sum \\
\hline Control & $\mathrm{bDL}$ & $1.05^{\mathrm{e}}$ & $6.89^{\mathrm{cd}}$ & $7.93^{\mathrm{bc}}$ \\
$\mathrm{Fe}_{5}$ & $\mathrm{bDL}$ & $\mathrm{bDL}$ & $3.60^{\mathrm{de}}$ & $3.60^{\mathrm{cd}}$ \\
$\mathrm{Fe}_{10}$ & $\mathrm{bDL}$ & $\mathrm{bDL}$ & $1.98^{\mathrm{e}}$ & $1.98^{\mathrm{d}}$ \\
$\mathrm{Fe}_{15}$ & $\mathrm{bDL}$ & $\mathrm{bDL}$ & $4.89^{\mathrm{cde}}$ & $4.90^{\mathrm{bcd}}$ \\
$\mathrm{Fe}_{5} \mathrm{Ca}$ & $\mathrm{bDL}$ & $1.19^{\mathrm{d}}$ & $6.98^{\mathrm{cd}}$ & $8.16^{\mathrm{bc}}$ \\
$\mathrm{Fe}_{10} \mathrm{Ca}_{5}$ & $\mathrm{bDL}$ & $\mathrm{bDL}$ & $6.12^{\mathrm{cd}}$ & $6.12^{\mathrm{bc}}$ \\
$\mathrm{Fe}_{15} \mathrm{Ca}_{5}$ & $\mathrm{bDL}$ & $1.63^{\mathrm{a}}$ & $36.4^{\mathrm{a}}$ & $38.0^{\mathrm{a}}$ \\
$\mathrm{Fe}_{5} \mathrm{Ca}_{10}$ & $\mathrm{bDL}$ & $1.30^{\mathrm{c}}$ & $8.83^{\mathrm{c}}$ & $10.1^{\mathrm{b}}$ \\
$\mathrm{Fe}_{10} \mathrm{Ca}_{10}$ & 8.32 & $1.47^{\mathrm{b}}$ & $28.6^{\mathrm{b}}$ & $38.3^{\mathrm{a}}$ \\
$\mathrm{Fe}_{15} \mathrm{Ca}_{10}$ & $\mathrm{bDL}$ & $1.10^{\mathrm{e}}$ & $5.39^{\mathrm{cde}}$ & $6.46^{\mathrm{bc}}$
\end{tabular}

$n=5$; identical superscripts in columns denote no significant differences between means according to a post-hoc Tukey's HSD test at $\alpha=95 \%$ following one-way ANOVA, bDL-below detection limit.

\section{Discussion}

Although the problem has been well known for over 50 years, ID remains the most common cause of anaemia worldwide and affects approximately 1-2 billion people of all age groups $[28,29]$. The major factors are reduction or complete absence of metal intake; an 
agricultural revolution that resulted in animal foods rich in bioavailable Fe being displaced by cereals, legumes, and plant-based diets; as well as the poor condition of the soils in which the consumed plants grow [30]. The critical issue is the bioavailability of $\mathrm{Fe}$, and it has been estimated to be in the range of $14-18 \%$ for mixed diets and $5-12 \%$ for vegetarian diets. Dietary factors that influence Fe absorption, such as ascorbic acid, Ca intake, phytate, polyphenols, and muscle tissue, have been identified repeatedly [31]. Hence, there is need to search for new sources of the element, including fortification products.

It has been confirmed that mushrooms can bioaccumulate several metals of nutritional and pharmacological importance [32-34]. More and more reports of attempts to supplement mushrooms with Fe can also be found in the literature. Almeida et al. [35] showed cultivation variables to increase Fe bioaccumulation in Pleurotus ostreatus mycelium. The effect of culture medium modifications: $\mathrm{Fe}\left(50\right.$ or $\left.150 \mathrm{mg} \mathrm{L}^{-1}\right)$, carbon (glucose or carboxymethyl cellulose), nitrogen (hydrolyzed casein or yeast extract), and $\mathrm{pH}$ (4.5 or 6.5) have been evaluated. Yokota et al. [36] examined P. ostreatus cultivated on substrate supplemented with various Fe concentrations (from 50 to $5000 \mathrm{mg} \mathrm{kg}^{-15} \mathrm{DW}$, which correspond to from 25 to $2500 \mathrm{mg} \mathrm{L}^{-1}$ ). Biological efficiency, metal content, bioavailability, the content of ashes, proteins and antioxidant activity have been determined. Umeo et al. [37] considered the bioaccumulation capacity of Agaricus subrufescens grown on Fe enriched substrate $\left(50 \mathrm{mg} \mathrm{L}^{-1}\right)$. The authors described mycelial biomass and the concentration of bioaccumulated Fe. The research team of Meniqueti et al. [38] also investigated Fe fortification in the mushroom species A. subrufescens, Ganoderma lucidum, P. eryngi, P. ostreatus, and Schizophyllum commune under different metal doses $\left(10-100 \mathrm{mg} \mathrm{L}^{-1}\right)$. Our experiment described the effect of 5, 10, and $15 \mathrm{mM} \mathrm{Fe}$ (corresponding to 280, 560, and $840 \mathrm{mg} \mathrm{L}^{-1}$ ) added to the mushroom medium. Compared to the additives used by other authors, these are relatively high concentrations.

A common observation for mentioned in the previous paragraph studies was the reduction of the biomass obtained in the presence of Fe addition. In our study, biomass decreased to 97,89 , and $61 \%$ (for 5,10 , and $15 \mathrm{mM} \mathrm{Fe}$ ) compared to the control. Almeida et al. [35] also reported a strong growth decrease in P. ostreatus for Fe doses above $150 \mathrm{mg} \mathrm{L}^{-1}$ and no growth at $300 \mathrm{mg} \mathrm{L}^{-1}$. Significant growth reduction with Fe addition above $300 \mathrm{mg} \mathrm{L}^{-1}$ and total inhibition above $750 \mathrm{mg} \mathrm{L}^{-1}$ was described for P. ostreatus by Yokota et al. [36]. What is more, from the 14 A. subrufescens strains tested by Umeo et al. [37], 12 were characterized by lower biomass production when $50 \mathrm{mg} \mathrm{L}^{-1} \mathrm{Fe}$ was added (ranging from 19 to $85 \%$ compared to the control). A similar observation was made by Meniqueti et al. [38], where $100 \mathrm{mg} \mathrm{L}^{-1}$ Fe doses caused a reduction in the mycelial biomass of $A$. subrufescens, P. eryngii, P. ostreatus, and S. commune (43, 6, 37 and $52 \%$ of the control). However, it should be mentioned that in the same experiment, G. lucidum and P. eryngii exposed to 50 and $30 \mathrm{mg} \mathrm{L}^{-1} \mathrm{Fe}$, respectively, showed 1.3-fold more biomass than the respective controls.

It is not surprising that the increased concentration of elements in the medium is usually associated with a more significant accumulation in mushrooms. In our study, mean Fe content in supplemented P. nameko was from almost 185 to $292 \%$ of the control, for Fe from 5 to $15 \mathrm{mM}$ added to the substrate, respectively. The crucial fact is that all the research cited above [35-38] mentioned similar results.

It is essential to look at different approaches to improve Fe contents and bioavailability from fortified foods. It seems promising to study the interactions between individual nutrients added to the medium in search of favourable intake and synergistic effects [39]. In our experiment, we added 5 and $10 \mathrm{mM}$ of $\mathrm{Ca}$ (which correspond to 200 and $400 \mathrm{mg} \mathrm{L}^{-1} \mathrm{Ca}$ ) as a modulating factor for $\mathrm{Fe}$ accumulation. The addition of the second element contributed to a further reduction in biomass production compared to systems supplemented only with Fe. For a dose of $5 \mathrm{mM}$ of Fe, the addition of 5 and $10 \mathrm{mM} \mathrm{Ca}$ resulted in 85 and $75 \%$; for a dose of $10 \mathrm{mM} \mathrm{Fe}, 77$ and $64 \%$ and for a dose of $15 \mathrm{mM} \mathrm{Fe}, 93$ and $37 \%$ biomass compared to the only Fe-fortified ones, respectively.

Most importantly, the supplementation of Ca to the medium increased the accumulation of Fe by the tested mushrooms. The addition of $5 \mathrm{mM}$ Ca resulted in 145, 125, 
and $126 \%$ of Fe accumulation concerning mushrooms grown on the medium with 5, 10, and $15 \mathrm{mM} \mathrm{Fe}$ addition only. Also, adding 10 and $15 \mathrm{mM} \mathrm{Ca}$ to Fe-fortified substrate resulted in a higher accumulation of $\mathrm{Fe}$ than for systems with only Fe addition. The highest increase, $153 \%$ of Fe content in mushrooms growing on $15 \mathrm{mM} \mathrm{Fe}$, was observed when $10 \mathrm{mM}$ Ca was simultaneously added to the substrate. Although we could not find any literature data on similar mushroom supplementation of Fe with the addition of $\mathrm{Ca}$, we can try to find common conclusions from the coincident supplementation of other elements. Scheid et al. [39] explored Fe biofortification and availability of fortification Lentinus crinitus, G. lucidum, S. commune, P. ostreatus, P. eryngii and Lentinula edodes. Mushrooms were grown on malt-extract or sugarcane molasses with different concentrations of Fe (0.116 and $91.23 \mathrm{mg} \mathrm{L}^{-1}$, respectively) as well as $\mathrm{Mg}\left(260.0\right.$ and $903.1 \mu \mathrm{g} \mathrm{L}{ }^{-1}$, respectively). The obtained observations are a component of all the factors that differed in both systems. Nevertheless, it can be concluded that for five from seven species, the medium with higher $\mathrm{Fe}$ and $\mathrm{Mg}$ concentrations showed higher mycelial biomass growth, and for all tested species, mushrooms grown on this medium accumulated significantly higher contents of Fe. The differences in $\mathrm{Mg}$ concentration probably influenced these observations. Interestingly, studies of the effect of the addition of Mn to Fe-fortified substrate on the growth and accumulation of $L$. crinitus have been published by Meniqueti et al. [40]. The authors tested the effect of $\mathrm{Mn}\left(0.9 \mathrm{mg} \mathrm{L}^{-1}\right)$ on mushroom growth, bioaccumulation, and transfer of Fe at different cultivation times $(7,14$, and 21 days) in a culture medium. Iron and $\mathrm{Mn}$ added to the substrate did not biomass affect growth. Manganese increased Fe bioaccumulation by up to two-fold when compared to Fe-fortification only.

Phenolic compounds are responsible for many functions which are connected with the ability to scavenge free radicals with a chelating ability to ions. In food, phenolic compounds are advisable because they increase the consumption value of the product. The phenolic composition of $P$. nameko has not been widely studied. The few studies that are available indicate that the composition is very poor [41,42], however TP content was similar to other species. The obtained results also show that the profile of phenolic compounds in $P$. nameko is rather poor; only four phenolic acids were quantified. Supplementation with Fe has a very favorable effect on the synthesis of 4-HBA and causes a significant increase in the acid. Some mixtures of $\mathrm{Fe}$ and $\mathrm{Ca}$ in different concentrations affects the elevation of synthesis of phenolic acids. Supplementation modified the profile and initiated the synthesis of some new components in comparison to the control, and significantly increased TP content. In the earlier studies on the supplementation of $P$. nameko substrates with Se salts, a significant increase in individual phenolic compounds and TP was achieved [41]. The increase in TP content in mushrooms was confirmed for Se-enrichment $[33,43,44]$. Mineral enrichment is recognized as a method of promoting the increase of health benefits of food. However, in P. nameko, enriched by Fe and $\mathrm{Ca}$, no spectacular changes in phenolic composition were recorded. Similar results were obtained by Fontes Vieira et al. [45] on P. ostreatus enriched with Fe which showed no differences in TP between enriched and non-enriched mushrooms. The effect of enrichment of substrates by different elements on biosynthesis is still not recognized. Changes in the phenolic content of enriched mushrooms are probably the result of activation or deactivation of the biochemical pathway at various stages, which may have been influenced by the type of salt in enriched substrate.

Organic acids are important constituents of mushroom taste components, which have a close relation to synthesis of phenolic compounds, amino acids, esters, and metabolic process of aroma components [44,45]. However, their most important function, besides phenolic compound synthesis, is that organic acids are known to possess antioxidative properties [46,47] having specific health effects, and even though they are non-nutritive compounds, some of them have been detected in different fungal species [48]. Moreover, the currently published literature data shows that the existence of a different profile and content of the determined acids in similar fruit bodies, of both wild and cultivated species, results from the occurrence of a diverse growth environment (specific climate combined with microhabitual characteristic) [49]. In P. nameko, the content of organic acids is limited, 
and only two dominant acids (succinic and citric) were identified, which from the entire spectrum of these compounds constitute a small percentage. Supplementation with Fe led to the lower synthesis of succinic acid in comparison to the control, while the mixture of Fe and $\mathrm{Ca}$ in different concentrations resulted in its elevation, and the simultaneous creation of citric acid. Supplementation modified the profile and initiated the synthesis of citric acids and significantly increased the content in comparison to the control. Succinic acid has been found in fruit bodies of various species of fungi such as L. fumosum, L. gilva, and L. scabrum [48], as well as in L. edodes, for which a significant increase was found when using a substrate with a high content of high $\mathrm{C} / \mathrm{N}$ values [44].

Furthermore, research results indicate that regular consumption of edible mushrooms in the human diet or their nutritional supplements can provide health benefits by improving antioxidant defense mechanisms and reducing the risk of chronic diseases [49,50]. Possible mechanisms of the antioxidant activity of mushroom species can be attributed to their strong hydrogen donation capacity or their effectiveness as good free radical scavengers, including the organic acids analyzed in our study $[24,51]$. Nevertheless, the presented study showed that $P$. nameko cannot be used as a readily available source of strong natural antioxidants and antimicrobials or as a viable dietary supplement, or in the food and pharmaceutical industries due to the fact that the amount of organic acids in the fruiting bodies was very limited.

The results showed that supplementation of $P$. nameko by Fe and Ca does not improve the phenolic composition of fruiting bodies. The modification of phenolic composition, the content of each compound, TP and organic acids has little impact. However, increasing the Fe content in fruit bodies may be a cost-effective method of improving the quality of the fruiting bodies for the consumer. Recommended dietary Fe intake for adult females and males has been estimated as $9-15$ and 6-11 $\mathrm{mg} \mathrm{day}^{-1}$, respectively [52,53]. Assuming the standard dose of mushroom consumption as $25 \mathrm{~g}$ DW per day, it can be calculated that a product from the $\mathrm{Fe}_{15}$ system will provide less than $5 \%$ and $7 \%$, while one from the $\mathrm{Fe}_{15} \mathrm{Ca}_{10}$ system will provide almost $8 \%$ and $11 \%$ of the daily requirement for $\mathrm{Fe}$, for females and males, respectively. At the same time, an increased Ca content can be an added value. Recommended dietary $\mathrm{Ca}$ intake for an adult male has been estimated as 900-1200 mg day ${ }^{-1}[54,55]$. Mushrooms from the $\mathrm{Fe}_{15}$ system will provide less than $1 \%$, while those from the $\mathrm{Fe}_{15} \mathrm{Ca}_{10}$ system will provide $4 \%$ of the daily requirement of $\mathrm{Ca}$.

\section{Conclusions}

Despite the enormous advancement in knowledge about food and nutrition, ID is one of the leading contributors to the worldwide burden of disease. Due to the fact that ID is common, additional sources of this element should be sought. Mushrooms can be a valuable food for Fe supplementation, but some modifications are necessary. Utilizing the effect of the interaction of other elements with Fe during supplementation on increasing the amount of metal intake is highly promising. The supplementation with Fe and simultaneous addition of Ca described in our study could be a starting point for planning the practical application of such cultivation. Of course, further research requires a reliable assessment of the bioavailability of Fe in such mushrooms in the gastrointestinal tract in order to assess to what extent the fruiting bodies will satisfy the demand for Fe and also Ca due to its accumulation. There is also no doubt that above conclusions will only be relevant if, from the point of view of the economics of mushroom growing, the decisive parameter will not be the amount of harvest, but the quality of product.

Supplementary Materials: The following are available online at https:/ /www.mdpi.com/article/10 .3390 / plants10112275/s1, Table S1: Parameters of analytical procedure, Table S2: Content $\left[\mathrm{mg} \mathrm{kg}^{-1}\right.$ ] of determined elements in Pholiota nameko fruit bodies.

Author Contributions: Conceptualization, M.S., M.M. and P.R.; methodology, P.N., S.B. and P.K.; software, A.B.; formal analysis, S.B., M.G., Z.M.; investigation, M.G., M.M., S.B., Z.M.; data curation, M.M. and A.B.; writing—original draft preparation, M.G., M.M., S.B. and Z.M.; writing-review and 
editing, M.M., S.B. and Z.M.; visualization, M.M.; supervision, P.K. and P.R. All authors have read and agreed to the published version of the manuscript.

Funding: This research received no external funding.

Acknowledgments: The authors gratefully acknowledge Andrzej Szarłata graphical assistance (andrzej.szarlata@gmail.com).

Conflicts of Interest: The authors declare no conflict of interest.

\section{References}

1. Nguyen, P.H.; Scott, S.; Headey, D.; Singh, N.; Tran, L.M.; Menon, P.; Ruel, M.T. The Double Burden of Malnutrition in India: Trends and Inequalities (2006-2016). PLoS ONE 2021, 16, e0247856. [CrossRef]

2. Barzegar, F.; Kamankesh, M.; Mohammadi, A. Recent Development in Formation, Toxic Effects, Human Health and Analytical Techniques of Food Contaminants. Food Rev. Int. 2021. [CrossRef]

3. Sellamuthu, K.M.; Malathi, P. Biofortification of Crops to Overcome Malnutrition in India. Biot. Res. Today 2021, 3, $402-405$.

4. Poniedziałek, B.; Perkowska, K.; Rzymski, P. Food Fortification. In Vitamins and Minerals Biofortification of Edible Plants; WileyBlackwell: Hoboken, NJ, USA, 2020; pp. 27-44. [CrossRef]

5. Olson, R.; Gavin-Smith, B.; Ferraboschi, C.; Kraemer, K.; Davaasambuu, G. Food Fortification: The Advantages, Disadvantages and Lessons from Sight and Life Programs. Nutrients 2021, 13, 1118. [CrossRef]

6. Wakeel, A.; Farooq, M.; Bashir, K.; Ozturk, L. Micronutrient Malnutrition and Biofortification: Recent Advances and Future Perspectives. In Plant Macronutrient Use Efficiency Molecular and Genomic Perspectives in Crop Plants; Elsevier: Amsterdam, The Netherlands, 2018; pp. 225-243. [CrossRef]

7. Buturi, C.V.; Mauro, R.P.; Fogliano, V.; Leonardi, C.; Giuffrida, F. Mineral Biofortification of Vegetables as a Tool to Improve Human Diet. Foods 2021, 10, 223. [CrossRef]

8. Riaz, N.; Guerinot, M.L. All Together Now: Regulation of the Iron Deficiency Response. J. Exp. Bot. 2021, 72, 2045-2055. [CrossRef]

9. Henjum, S.; Groufh-Jacobsen, S.; Stea, T.H.; Tonheim, L.E.; Almendingen, K. Iron Status of Vegans, Vegetarians and Pescatarians in Norway. Biomolecules 2021, 11, 454. [CrossRef] [PubMed]

10. Venkataramani, V. Iron Homeostasis and Metabolism: Two Sides of a Coin. Adv. Exp. Med. Biol. 2021, 1301, 25-40. [CrossRef]

11. Pasricha, S.-R.; Tye-Din, J.; Muckenthaler, M.U.; Swinkels, D.W. Iron Deficiency. Lancet 2021, 397, 233-248. [CrossRef]

12. Man, Y.; Xu, T.; Adhikari, B.; Zhou, C.; Wang, Y.; Wang, B. Iron Supplementation and Iron-Fortified Foods: A Review. Crit. Rev. Food Sci. Nutr. 2021, 1-22. [CrossRef]

13. Quintaes, K.D.; Barberá, R.; Cilla, A. Iron Bioavailability in Iron-Fortified Cereal Foods: The Contribution of in Vitro Studies. Crit. Rev. Food Sci. Nutr. 2017, 57, 2028-2041. [CrossRef] [PubMed]

14. Beinner, M.A.; Lamounier, J.A.; Tomaz, C. Effect of Iron-Fortified Drinking Water of Daycare Facilities on the Hemoglobin Status of Young Children. J. Am. Coll. Nutr. 2013, 24, 107-114. [CrossRef] [PubMed]

15. Hekmat, S.; Mcmahon, D.J. Manufacture and Quality of Iron-Fortified Yogurt. J. Dairy Sci. 1997, 80, 3114-3122. [CrossRef]

16. Larson, L.M.; Cyriac, S.; Djimeu, E.W.; Mbuya, M.N.N.; Neufeld, L.M. Can Double Fortification of Salt with Iron and Iodine Reduce Anemia, Iron Deficiency Anemia, Iron Deficiency, Iodine Deficiency, and Functional Outcomes? Evidence of Efficacy, Effectiveness, and Safety. J. Nutr. 2021, 151, 15S-28S. [CrossRef]

17. Hurrell, R.F. Efficacy and safety of iron fortification. In Food Fortification in a Globalized World; Academic Press: London, UK, 2018; pp. 196-212. [CrossRef]

18. Chopra, H.; Mishra, A.K.; Baig, A.A.; Mohanta, T.K.; Mohanta, Y.K.; Baek, K.-H. Narrative Review: Bioactive Potential of Various Mushrooms as the Treasure of Versatile Therapeutic Natural Product. J. Fungi 2021, 7, 728. [CrossRef]

19. Friedman, M. Mushroom Polysaccharides: Chemistry and Antiobesity, Antidiabetes, Anticancer, and Antibiotic Properties in Cells, Rodents, and Humans. Foods 2016, 5, 80. [CrossRef]

20. Yue, G.G.-L.; Lau, C.B.-S.; Leung, P.-C. Medicinal Plants and Mushrooms with Immunomodulatory and Anticancer Properties-A Review on Hong Kong's Experience. Molecules 2021, 26, 2173. [CrossRef]

21. Oyetayo, V.O.; Ogidi, C.O.; Bayode, S.O.; Enikanselu, F.F. Evaluation of Biological Efficiency, Nutrient Contents and Antioxidant Activity of Pleurotus pulmonarius Enriched with Zinc and Iron. Indian Phytopathol. 2021, 1-10. [CrossRef]

22. Windisch, W. Interaction of Chemical Species with Biological Regulation of the Metabolism of Essential Trace Elements. Anal. Bioanal. Chem. 2001, 372, 421-425. [CrossRef]

23. Stamets, P. Growing Gourmet and Medicinal Mushrooms Paul Stamets; Ten Speed Press: Berkeley, CA, USA, $2000 ;$ ISBN 1580081754.

24. Gąsecka, M.; Magdziak, Z.; Siwulski, M.; Jasińska, A.; Budzyńska, S.; Rzymski, P.; Kalač, P.; Niedzielski, P.; Pankiewicz, J.; Mleczek, M. Effect of Thymus Vulgaris Post-Extraction Waste and Spent Coffee Grounds on the Quality of Cultivated Pleurotus Eryngii. J. Food Process. Preserv. 2020, 44, e14648. [CrossRef]

25. Singleton, V.L.; Orthofer, R.; Lamuela-Raventós, R.M. Analysis of Total Phenols and Other Oxidation Substrates and Antioxidants by Means of Folin-Ciocalteu Reagent. Methods Enzymol. 1999, 299, 152-178. [CrossRef] 
26. Falniowski, A. The Numerical Methods in Taxonomy, 1st ed.; Metody Numeryczne w Taksonomii; Wydawnictwo Uniwersytetu Jagiellońskiego: Kraków, Poland, 2003; ISBN 83-233-1745-3.

27. Galili, T. Dendextend: An R Package for Visualizing, Adjusting and Comparing Trees of Hierarchical Clustering. Bioinformatics 2015, 31, 3718-3720. [CrossRef]

28. World Health Organization. The Global Prevalence of Anaemia in 2011; World Health Organization: Geneva, Switzerland, 2015.

29. Benson, C.S.; Shah, A.; Stanworth, S.J.; Frise, C.J.; Spiby, H.; Lax, S.J.; Murray, J.; Klein, A.A. The Effect of Iron Deficiency and Anaemia on Women's Health. Anaesthesia 2021, 76, 84-95. [CrossRef]

30. Lynch, S.R. Why Nutritional Iron Deficiency Persists as a Worldwide Problem. J. Nutr. 2011, 141, 763S-768S. [CrossRef]

31. Hurrell, R.F. Iron Fortification Practices and Implications for Iron Addition to Salt. J. Nutr. 2021, 151, 3S-14S. [CrossRef] [PubMed]

32. Zięba, P.; Kała, K.; Włodarczyk, A.; Szewczyk, A.; Kunicki, E.; Sękara, A.; Muszyńska, B. Selenium and Zinc Biofortification of Pleurotus Eryngii Mycelium and Fruiting Bodies as a Tool for Controlling Their Biological Activity. Molecules 2020, 25, 889. [CrossRef]

33. Rzymski, P.; Niedzielski, P.; Siwulski, M.; Mleczek, M.; Budzyńska, S.; Gąsecka, M.; Poniedziałek, B. Lithium Biofortification of Medicinal Mushrooms Agrocybe Cylindracea and Hericium Erinaceus. J. Food Sci. Technol. 2017, 54, 2387-2393. [CrossRef] [PubMed]

34. Gąsecka, M.; Mleczek, M.; Siwulski, M.; Niedzielski, P. Phenolic Composition and Antioxidant Properties of Pleurotus Ostreatus and Pleurotus Eryngii Enriched with Selenium and Zinc. Eur. Food Res. Technol. 2015, 242, 723-732. [CrossRef]

35. Almeida, S.M.; Umeo, S.H.; Marcante, R.C.; Yokota, M.E.; Valle, J.S.; Dragunski, D.C.; Colauto, N.B.; Linde, G.A. Iron Bioaccumulation in Mycelium of Pleurotus Ostreatus. Braz. J. Microbiol. 2015, 46, 195-200. [CrossRef]

36. Yokota, M.E.; Frison, P.S.; Marcante, R.C.; Jorge, L.F.; Valle, J.S.; Dragunski, D.C.; Colauto, N.B.; Linde, G.A. Iron Translocation in Pleurotus Ostreatus Basidiocarps: Production, Bioavailability, and Antioxidant Activity. Genet. Mol. Res. 2016, 15. [CrossRef]

37. Umeo, S.H.; Faria, M.G.I.; Vilande, S.S.S.; Dragunski, D.C.; do Valle, J.S.; Colauto, N.B.; Linde, G.A. Iron and Zinc Mycelial Bioaccumulation in Agaricus Subrufescens Strains. Semina: Ciências Agrárias 2019, 40, 2513-2522. [CrossRef]

38. Meniqueti, A.B.; Ruiz, S.P.; Faria, M.G.I.; Valle, J.S.; Gonçalves, A.C., Jr.; Dragunski, D.C.; Colauto, N.B.; Linde, G.A. Iron-Enriched Mycelia of Edible and Medicinal Basidiomycetes. Environ. Technol. 2020. [CrossRef] [PubMed]

39. Verna, G.; Sila, A.; Liso, M.; Mastronardi, M.; Chieppa, M.; Cena, H.; Campiglia, P. Iron-Enriched Nutritional Supplements for the 2030 Pharmacy Shelves. Nutrients 2021, 13, 378. [CrossRef] [PubMed]

40. Scheid, S.S.; Faria, M.G.I.; Velasquez, L.G.; do Valle, J.S.; Gonçalves, A.C.; Dragunski, D.C.; Colauto, N.B.; Linde, G.A. Iron Biofortification and Availability in the Mycelial Biomass of Edible and Medicinal Basidiomycetes Cultivated in Sugarcane Molasses. Sci. Rep. 2020, 10, 12875. [CrossRef] [PubMed]

41. Meniqueti, A.B.; Ruiz, S.P.; Faria, M.G.I.; do Valle, J.S.; Gonçalves, A.C., Jr.; Dragunski, D.C.; Colauto, N.B.; Linde, G.A. Iron Bioaccumulation in Lentinus Crinitus Mycelia Cultivated in Agroindustrial Byproducts. Waste Biomass Valorization 2021, 12, 4965-4974. [CrossRef]

42. Gasecka, M.; Mleczek, M.; Siwulski, M.; Niedzielski, P.; Kozak, L. The Effect of Selenium on Phenolics and Flavonoids in Selected Edible White Rot Fungi. LWT Food Sci. Technol. 2015, 63, 726-731. [CrossRef]

43. Lin, S.; Ching, L.T.; Ke, X.; Cheung, P.C.K. Comparison of the Composition and Antioxidant Activities of Phenolics from the Fruiting Bodies of Cultivated Asian Culinary-Medicinal Mushrooms. Int. J. Med. Mushrooms 2016, 18, 871-881. [CrossRef]

44. Wang, B.; Zhao, N.; Li, J.; Xu, R.; Wang, T.; Guo, L.; Ma, M.; Fan, M.; Wei, X. Selenium-Enriched Lactobacillus Plantarum Improves the Antioxidant Activity and Flavor Properties of Fermented Pleurotus Eryngii. Food Chem. 2021, 345. [CrossRef]

45. Vieira, P.A.F.; Gontijo, D.C.; Vieira, B.C.; Fontes, E.A.; de Assunção, L.S.; Leite, J.; Oliveira, M.G.D.A.; Kasuya, M.C.M. Antioxidant Activities, Total Phenolics and Metal Contents in Pleurotus Ostreatus Mushrooms Enriched with Iron, Zinc or Lithium. LWT Food Sci. Technol. 2013, 54, 421-425. [CrossRef]

46. Li, W.; Chen, W.; Yang, Y.; Zhang, J.; Feng, J.; Yu, H.; Zhou, S.; Li, X.; Liu, Y. Effects of Culture Substrates on Taste Component Content and Taste Quality of Lentinula Edodes. Int. J. Food Sci. Technol. 2017, 52, 981-991. [CrossRef]

47. Yang, Y.; Gu, Z.; Liu, Y.F.; Zhou, S.; Zhang, J.S. Determination of Seven Organic Acids in Edible Fungi by Reversed-Phase High Performance Liquid Chromatography. Mycosystema 2013, 32, 1064-1070.

48. Ferreira, I.; Barros, L.; Abreu, R. Antioxidants in Wild Mushrooms. Curr. Med. Chem. 2009, 16, 1543-1560. [CrossRef]

49. Ribeiro, B.; Valentão, P.; Baptista, P.; Seabra, R.M.; Andrade, P.B. Phenolic Compounds, Organic Acids Profiles and Antioxidative Properties of Beefsteak Fungus (Fistulina Hepatica). Food Chem. Toxicol. 2007, 45, 1805-1813. [CrossRef] [PubMed]

50. Magdziak, Z.; Siwulski, M.; Mleczek, M. Characteristics of Organic Acid Profiles in 16 Species of Wild Growing Edible Mushrooms. J. Environ. Sci. Health Part B 2017, 52, 784-789. [CrossRef]

51. Karaman, M.; Stahl, M.; Vulić, J.; Vesić, M.; Čanadanović-Brunet, J. Wild-Growing Lignicolous Mushroom Species as Sources of Novel Agents with Antioxidative and Antibacterial Potentials. Int. J. Food Sci. Nutr. 2014, 65, 311-319. [CrossRef]

52. Cardoso, R.V.C.; Carocho, M.; Fernandes, Â.; Pinela, J.; Stojković, D.; Soković, M.; Zied, D.C.; Cobos, J.D.V.; González-Paramás, A.M.; Ferreira, I.C.F.R.; et al. Antioxidant and Antimicrobial Influence on Oyster Mushrooms (Pleurotus Ostreatus) from Substrate Supplementation of Calcium Silicate. Sustainability 2021, 13, 5019. [CrossRef]

53. Stojković, D.S.; Kovačević-Grujičić, N.; Reis, F.S.; Davidović, S.; Barros, L.; Popović, J.; Petrović, I.; Pavić, A.; Glamočlija, J.; Ćirić, A.; et al. Chemical Composition of the Mushroom Meripilus Giganteus Karst. and Bioactive Properties of Its Methanolic Extract. LWT Food Sci. Technol. 2017, 79, 454-462. [CrossRef] 
54. National Health Service Vitamins and Minerals-NHS. Available online: https://www.nhs.uk/conditions/vitamins-andminerals / (accessed on 2 October 2021).

55. EFSA Panel on Dietetic Products, Nutrition and Allergies (NDA). Scientific Opinion on Dietary Reference Values for Iron. EFSA J. 2015, 13, 115. [CrossRef] 